Violetta Kopińska

Uniwersytet Mikołaja Kopernika

E-MAIL: violetta.kopinska@umk.pl

\title{
Zmiana polskich podstaw programowych kształcenia ogólnego w zakresie kompetencji społecznych i obywatelskich. Analiza krytyczna
}

\section{STRESZCZENIE}

W roku szkolnym 2017/2018 zaczęła obowiązywać w Polsce nowa podstawa programowa dla szkół podstawowych. Wcześniejsze zapowiedzi dotyczące reformy edukacji podkreślały znaczenie wychowania w szkole, akcentując przy tym rozwój społeczny uczniów i uczennic oraz wychowanie obywatelskie. Wobec tego, celem badań, których wyniki są prezentowane w tym artykule było ustalenie zakresu zmian nowych podstaw programowych kształcenia ogólnego w odniesieniu do artykułowanych tam kompetencji społecznych i obywatelskich. Metodą zbierania danych zastosowaną w badaniach było przeszukiwanie źródeł wtórnych, a metodą analizy danych - analiza treści. Wyniki wskazują, że „nowa” podstawa programowa utrwala, podobnie jak „stara”, tradycyjny - transmisyjny model edukacji i obywatelstwo socjalizacyjne. Wniosek ten wynika zarówno z ogólnej analizy struktury zapisanych tam wymagań, jak i analiz szczegółowych, odnoszących się zarówno do eksponowanych, jak i marginalizowanych kategorii analitycznych. To pozwala sądzić, że decyzja dotycząca zmiany podstaw programowych nie miała nic wspólnego z rzeczywistym reformowaniem edukacji.

sŁowa KLUCzowe: podstawa programowa, szkoła, kompetencje społeczne, kompetencje obywatelskie

\section{Wprowadzenie}

Celem niniejszego artykułu jest ustalenie zakresu zmian „nowych” podstaw programowych kształcenia ogólnego w odniesieniu do artykułowanych tam kompetencji społecznych i obywatelskich. Realizacja tego celu pozwoli być może również na odsłonięcie rzeczywistego celu tej zmiany. Czy motywacja do zmiany podstaw programowych, a poprzez to - kształt nowych podstaw, jest zmianą rzeczywistą, tzn. merytorycznie uzasadnioną, opartą na krytyce „starych” podstaw programowych, zmieniającą zasadniczo zakładany kształt edukacji społecznej i obywatelskiej? Takie postawienie celu wymaga wyjaśnienia i uzasadnienia. 
Podstawy programowe w Polsce wprowadzane są aktem prawnym $\mathrm{w}$ randze rozporządzenia ministerialnego, co nadaje im wysoką pozycję w hierarchii aktów prawnych (akt prawny powszechnie obowiązujący). Ich waga nie wynika jednak tylko $\mathrm{z}$ tego faktu. Analiza całego kompleksu przepisów prawa oświatowego prowadzi do wniosku, że mają one istotne znaczenie w polskiej edukacji, ponieważ stanowią zasadnicze kryterium oceny programów nauczania, kryterium oceniania uczniów i uczennic i formułowania wymagań egzaminacyjnych, a ich realizacja jest jednym z podstawowych obszarów ewaluacji dokonywanej przez organy nadzoru pedagogicznego (Kopińska i Solarczyk-Szwec, 2017b, s. 78-79). Nie oznacza to jednak, że efekty uczenia się osiągane przez uczniów i uczennice w wyniku edukacji szkolnej są tożsame $z$ efektami zakładanymi w podstawach programowych. Niemniej jednak trudno nie zgodzić się z tym, że na podstawie analizy podstaw programowych można zrekonstruować zakładany kształt edukacji, w tym - edukacji obywatelskiej.

Szczegółowe analizy podstaw programowych mogą zatem wydobywać na światło dzienne ukryte sensy tej edukacji oraz obnażać ich błędy zarówno o charakterze merytorycznym, jak i dydaktycznym, ale także sprawdzać, na ile wizja kształcenia deklarowana publicznie znajduje swoje potwierdzenie w obowiązującym dokumencie i czy jest oparta na naukowych podstawach dotyczących rozwoju człowieka. Analizy te wydają się cenne zwłaszcza $\mathrm{w}$ czasie, gdy zmiany podstaw programowych przygotowywane są $\mathrm{w}$ szybkim tempie, co gwarantuje „sukces polityczny”, ale nie daje możliwości na istotną merytorycznie debatę społeczną (nie tylko pedagogiczną), dotyczącą kształtu podstaw programowych nie tylko w zakresie poszczególnych wymagań wpisujących się w określone szkolne przedmioty, czy koordynacji międzyprzedmiotowej (co jest dużo trudniejsze) ${ }^{1}$, ale - co najważniejsze - na temat samej koncepcji podstaw programowych. W rezultacie wprowadzane zmiany mają charakter kosmetyczny. Nie chodzi przy tym o to, że nie zmieniają wymagań w stosunku do uczniów i uczennic (a poprzez to treści kształcenia formułowanych w podstawach programowych kształcenia ogólnego). Zmieniają, w przypadku niektórych przedmiotów - nawet dość istotnie. Chodzi jednak o to, że koncepcja tych podstaw, a przez to edukacji szkolnej, pozostaje bez zmiany. Kłótnie toczą się wokół konkretnych wymagań - co usunąć, co wstawić, a nie wokół samej koncepcji podstaw programowych. Nikt nie poddaje pod dyskusję faktu, że podstawa programowa jest katalogiem szczegółowo

1 Nierozumianej tylko jako powiązanie ze sobą treści występujących na „pokrewnych” przedmiotach, ale także jako systematyczne i równomierne rozwijanie na każdym etapie edukacyjnym różnych kompetencji, zwłaszcza tych o charakterze przekrojowym. 
zapisanych, zindywidualizownych efektów uczenia się, spośród których dominują te związane z funkcją rekonstrukcyjną i adaptacyjną szkoły (Solarczyk-Szwec i Kopińska, 2017, s. 215-230). Nikt nie kwestionuje tego, że operuje kodem kolekcji (Bernstein, 1990, s. 40) i charakteryzuje się silną klasyfikacją (s. 37-39) nie tylko w zakresie treści poszczególnych przedmiotów, ale również wewnątrzprzedmiotowo (Kopińska, 2017a, s. 206), co utrudnia fuzję wiedzy pochodzącej z różnych pól rekontekstualizacyjnych (Bernstein, 1990, s. 182-183) i co pozwala na kontrolę sprawowaną od wewnątrz za pomocą formowania określonych tożsamości (s. 48-49). Nikt nie kwestionuje silnej kontroli nad edukacją zapewnianej przez tak skonstruowane podstawy programowe. Nie mówiąc już o tym, że nikt nie kwestionuje zasadności ustanawiania podstaw programowych.

Od roku szkolnego 2017/2018 zaczęła obowiązywać w Polsce nowa podstawa programowa dla szkół podstawowych, która początkowo została wprowadzona do klas I, IV i VII. W roku szkolnym 2018/2019 jej zakres obowiązywania rozszerza się na klasy II, V, VIII. A w kolejnym roku obejmie już cała szkołę podstawową (a jednocześnie nowa podstawa programowa zacznie obowiązywać w szkołach ponadpodstawowych). Podstawa ta powstała w ciągu kilku miesięcy. Prace nad tym dokumentem trwały niespełna rok, wliczając w to miesięczny okres prekonsultacji publicznych i miesięczny okres konsultacji i uzgodnień resortowych ${ }^{2}$. To niebywałe tempo ustanawiania tego ważnego dla edukacji dokumentu sprzężone zostało z reformą struktury szkolnictwa.

Ponieważ wszelkie zapowiedzi dotyczące reformy edukacji podkreślały znaczenie wychowania w szkole, akcentując przy tym rozwój społeczny uczniów i uczennic oraz wychowanie obywatelskie, warto dokonać analizy dokumentu w tym zakresie.

\section{Metodologia}

Pytanie badawcze, które stało się podstawą do analizy podstaw programowych, której wyniki są prezentowane w niniejszym artykule brzmi: Jakie zmiany wprowadzają „nowe” podstawy programowe w zakresie zakładanych tam kompetencji społecznych i obywatelskich w porównaniu ze „starymi" podstawami programowymi?

Przedstawione tu wyniki badań pochodzą z projektu, którego celem jest identyfikacja i ocena kompetencji społecznych i obywatelskich, zawartych 2 https://podstawaprogramowa.pl/aktualnosci/nowa-podstawa-programowa-podpisana, 
w podstawach programowych kształcenia ogólnego, oraz potencjalnych skutków ich realizacji dla edukacji.

Metodą zbierania danych zastosowaną podczas badań jest przeszukiwanie źródeł - wtórnych (Rubacha, 2008, s. 157-164). Projekt miał swoją pierwszą edycję, w której próbę badawczą stanowiły tzw. stare podstawy programowe. Szczegółowe jego wyniki zostały opublikowane wkilku artykułach ${ }^{3}$ oraz w książce - Kompetencje społeczne i obywatelskie w podstawach programowych kształcenia ogólnego. Analiza krytyczna (Kopińska i Solarczyk-Szwec, red., 2017a). Obecnie trwa druga edycja projektu ${ }^{4}$, w którym próbę badawczą stanowią „nowe” podstawy programowe.

Projekt ten bazuje na metodologii zastosowanej w poprzedniej edycji badań (Kopińska, 2017b, s. 91-114). Analiza podstaw programowych koncentruje się na analizie treści i polega na wyszukiwaniu w wymaganiach szczegółowych w podstawach programowych określonych kategorii analitycznych, a w rezultacie - określania ich liczebności. Jednostką analizy było zatem wymaganie szczegółowe ${ }^{5}$, które stanowi wydzielony zapis, określający, jakie efekty uczenia się powinni osiągnąć uczniowie i uczennice po zakończeniu danego etapu edukacyjnego w ramach określonego przedmiotu. Przy analizie zastosowano triangulację badaczek (Rubacha, 2008, s. 87-88; Gibbs, 2011, s. 167-168). Każde wymaganie zostało ocenione przez co najmniej dwie badaczki. Katalog kategorii analitycznych zbudowany został z efektów uczenia się w zakresie kompetencji społecznych i obywatelskich, które zostały wyróżnione w trzech etapach. Pierwszy etap wyróżniania tych kategorii bazował

3 Kopińska, V. (2016). Wartości demokratyczne w szkole. Krytyczna analiza podstaw programowych kształcenia ogólnego. Rocznik Pedagogiczny, t. 39; Kopińska, V., Majchrzak, K., Szwech, A. (2017). Patriotyzm w edukacji szkolnej. Założenia podstaw programowych kształcenia ogólnego, Teraźniejszość - Człowiek - Edukacja, nr 1; Kopińska, V., Solarczyk-Szwec, H. (2016). Edukacja dla wspólnoty? Krytyczna analiza podstaw programowych kształcenia ogólnego. Forum Oświatowe, nr 2; Przyborowska, B., Kopińska, V., Murawska, I. (2016). Kompetencje społeczne i obywatelskie na trzecim etapie edukacyjnym - pozór podstawy programowej kształcenia ogólnego. Przegląd Badań Edukacyjnych, t. 23, nr 2; Solarczyk-Szwec, H. Matusiak, A., Kopińska, V. (2016). Kompetencje społeczne na wejściu w dorosłość. Krytyczna analiza podstawy programowej kształcenia ogólnego dla IV etapu edukacyjnego. Edukacja Dorosłych, nr 2; Symonowicz-Jabłońska, I., Wieczór, E. (2016). Budowanie kapitału społecznego w świetle analizy podstawy programowej dla pierwszego etapu edukacyjnego. Problemy Wczesnej Edukacji, t. 34, nr 4.

4 Projekt prowadzony jest przez Katedrę Pedagogiki Szkolnej, WNP, UMK w Toruniu i uczestniczą w nim: Violetta Kopińska, Beata Przyborowska, Hanna Solarczyk-Szwec, Izabela Symonowicz-Jabłońska, Kinga Majchrzak, Iwona Murawska.

5 W projekcie poddano analizie również wymagania ogólne, jednakże wyniki prezentowane w tym artykule ograniczają się do wymagań szczegółowych. 
na analizie dokumentów polityczno-oświatowych ${ }^{6}$. W drugim etapie katalog został uzupełniony na podstawie literatury przedmiotu?. I wreszcie na trzecim etapie dodano te kategorie, które wynikały już z samej analizy podstaw programowych i które nie miały dotychczas reprezentacji w skonstruowanym katalogu, a niewątpliwie mieściły się w zakresie kompetencji społecznych i obywatelskich. Powstały w ten sposób katalog bazuje zatem z jednej strony na dokumentach, których treść powinna zostać uwzględniona przy budowie podstaw programowych, samych podstawach programowych, operując również językiem do nich dostosowanym oraz - na różnorodnej literaturze przedmiotu, która pozwala wyjść poza „dostosowawczy” charakter katalogu i jednocześnie lepiej ocenić badany materiał (Kopińska, 2017b, s. 94-103). W pierwszej edycji badań wyróżniono 116 kategorii analitycznych ${ }^{8}$, w obecnej edycji jest ich (w chwili pisania artykułu - lipiec 2018) - 122. Różnica wynika $\mathrm{z}$ dostosowania kategorii analitycznych do badanych dokumentów. Warto przy tym podkreślić, że zmiany $\mathrm{w}$ tym katalogu związane są wyłącznie z poszerzaniem lub uszczegóławianiem określonych kategorii i nie oznaczają rezygnacji z żadnej kategorii. Dzięki temu możliwe jest porównanie wyników uzyskanych w obu edycjach badań.

Próba badawcza będąca podstawą analiz, których wyniki są zaprezentowane w niniejszym artykule objęła:

- podstawę programową do sześcioletniej szkoły podstawowej, opublikowaną w Załącziku nr 2 rozporządzenia Ministra Edukacji Narodowej $z$ dnia 27 sierpnia 2012 r. w sprawie podstawy programowej wychowania przedszkolnego oraz kształcenia ogólnego w poszczególnych typach szkót, Dz.U. 2012, poz. 977 ze zm. w brzmieniu ustalonym przez Załącznik nr 2 do rozporzadzenia Ministra Edukacji Narodowej z dnia 30 maja 2014 r. zmieniajacego rozporzadzenie w sprawie podstawy programowej wychowania przedszkolnego oraz kształcenia ogólnego w poszczególnych typach szkół, Dz.U. 2014, poz. 803, obejmującą pierwszy (klasy I-III) i drugi (IV-VI) etap edukacji

- podstawę programową do trzyletniego gimnazjum, opublikowaną w Załącziku $n r 4$ do rozporządzenia Ministra Edukacji Narodowej $z$ dnia 27 sierpnia 2012 r. w sprawie podstawy programowej wychowania

6 Lista dokumentów będących podstawą wyróżnienia tych kategorii znajduje się na końcu artykułu.

7 Lista literatury przedmiotu będącej podstawą wyróżnienia tych kategorii znajduje się na końcu artykułu.

8 Katalog tych kategorii został opublikowany w: Kopińska, 2017b, s. 98-102. 
przedszkolnego oraz kształcenia ogólnego w poszczególnych typach szkót, Dz.U. 2012, poz. 977 ze zm. ${ }^{9}$

- podstawę programową do ośmioletniej szkoły podstawowej, opublikowaną w Załączniku nr 2 do rozporzadzenia Ministra Edukacji Narodowej $z$ dnia 14 lutego 2017 r. w sprawie podstawy programowej wychowania przedszkolnego oraz podstawy programowej kształcenia ogólnego dla szkoły podstawowej, w tym dla uczniów z niepełnosprawnościa intelektualna w stopniu umiarkowanym lub znacznym, kształcenia ogólnego dla branżowej szkoły I stopnia, kształcenia ogólnego dla szkoły specjalnej przysposabiającej do pracy oraz kształcenia ogólnego dla szkoły policealnej, Dz.U. 2017, poz. 356, obejmującą pierwszy (klasy I-III) i drugi (IV-VIII) etap edukacji ${ }^{10}$.

Zestawienie tych właśnie dokumentów jest podyktowane zmianą struktury szkolnictwa. Nie jest to porównanie idealne, ponieważ porównywany jest dziewięcioletni okres edukacji szkolnej z okresem ośmioletnim, niemniej jednak inne porównanie nie jest możliwe ze względu na to, że podstawy programowe konstruowane są dla poszczególnych etapów edukacji, a nie lat ${ }^{11}$.

Analizie poddano wszystkie wymagania szczegółowe podstaw programowych skonstruowane dla przedmiotów obowiązkowych, etyki i wychowania do życia w rodzinie ${ }^{12}$, które zakwalifikowano jako te, które mieszczą się w zakresie kompetencji społecznych i obywatelskich. W wymaganiach tych poszukiwano poszczególnych kategorii analitycznych. Ze względu na fakt, że wymagania mają charakter rozbudowany, w każdym z nich można było zidentyfikować jedną lub więcej kategorii analitycznych. Ma to znaczenie dla odpowiedniego odczytywania wyników badań. Określają one liczbę lub procent wymagań, w których zidentyfikowano określone kategorie analityczne. Suma wyników ze wszystkich kategorii jest wobec tego większa niż liczba badanych wymagań, a w przypadku wyników przedstawianych w procentach nie sumuje się do stu (Kopińska, 2017b, s. 106-107). Biorąc pod uwagę rozu-

9 Dwa powyższe dokumenty określane są skrótowo w niniejszym artykule jako „stare” podstawy programowe, pamiętając jednocześnie, że oba mają obecnie status obowiązujący (w określonym zakresie).

Dokument ten określany jest skrótowo w niniejszym artykule „nową” podstawą programową

11 W nowej podstawie programowej wyróżniono wprawdzie, w odniesieniu do kilku (język polski, język obcy nowożytny, historia, matematyka, informatyka, wychowanie fizyczne) przedmiotów, wymagania dla VII i VIII klasy, ale nie dotyczy to wszystkich przedmiotów, a ponadto nie zmienia faktu, że ewentualne porównanie tych wymagań z wymaganiami skonstruowanymi dla trzyletniego gimnazjum nie likwiduje różnicy jednego roku nauki. Nie analizowano wymagań do przedmiotów język mniejszości narodowej i język regionalny. 
mienie kompetencji, zgodnie z którym są to struktury zbudowane $\mathrm{z}$ afektywnych, społecznych i kognitywnych komponentów (Góralska, Solarczyk-Szwec, 2012, s. 31), każde wymaganie z badanej grupy przyporządkowywano również do określonego obszaru(ów): wiedzy, umiejętności, postaw. Przyjęto przy tym następujące definicje operacyjne Anderson, Krathwohl, 2001; Krathwohl, Bloom, Masia, 1964; Simpson, 1972, za: Jankowski (brw); Polska Rama Kwalifikacji - Raport Referencyjny. Odniesienie Polskiej Ramy Kwalifikacji na rzecz uczenia się przez całe życie do Europejskiej Ramy Kwalifikacji, 2013:

\begin{abstract}
Wymaganie oceniane jako należące do obszaru wiedzy to takie, które składa się z efektów uczenia się koncentrujących się na pamiętaniu, odtwarzaniu z pamięci, tłumaczeniu, interpretacji, porównywaniu pojęć, faktów, terminologii, sposobów postępowania, metod i modeli. Przykładowe czasowniki, którymi operują efekty uczenia się z tego obszaru to: wyjaśnia, omawia, przedstawia, podaje, opisuje, charakteryzuje, wymienia, klasyfikuje, zna. Wymaganie oceniane jako należące do obszaru umiejętności to takie, które składa się z efektów uczenia się koncentrujących się na wykonywaniu określonych czynności (sfera psychomotoryczna) lub takich, które są związane z umiejętnościami intelektualnymi wyższego rzędu (projektowanie, konstruowanie, tworzenie, ocenianie, weryfikowanie). Wymaganie oceniane jako należące do obszaru postaw to takie, które składa się z efektów uczenia się odwołujących się do uczuć, zasad, wartościowania, gotowości do reagowania w określony sposób (sfera afektywna). (Kopińska, 2017b, s. 104)
\end{abstract}

Wymaganie mogło być również ocenione jako mieszane, jeżeli efekty uczenia się wchodzące w jego skład oceniane były jako mieszczące się w kilku określonych obszarach (Kopińska, 2017 b, s. 104).

Ponieważ podstawowymi funkcjami szkoły / edukacji są funkcje: rekonstrukcyjna, adaptacyjna i emancypacyjna (Kwieciński, 1995, s. 21), ocena badanych wymagań ze względu na pełnione przez nie funkcje stała się jedną ze zmiennych wykorzystywanych podczas analizy. Odwołując się do definicji funkcji szkoły / edukacji wyróżnionych przez Kwiecińskiego, ustalono, że:

1. „Wymagania oceniane jako rekonstrukcyjne to takie, których spełnienie wpisuje się w funkcję rekonstrukcyjną edukacji, polegającą «na odtwarzaniu kultury uniwersalnej i narodowej oraz na przekazywaniu jej wychowankom i na odtwarzaniu struktury społecznej»" (Kwieciński, 1995, s. 21; Kopińska, 2017b, s. 105). Przykładem wymagania z podstaw programowych ocenionego jako rekonstrukcyjne jest: „zbiera informacje na temat historii swojej rodziny, gromadzi pamiątki rodzinne i opowiada o nich".

2. „Wymagania oceniane jako adaptacyjne to takie, których osiągnięcie wpisuje się w funkcję adaptacyjną edukacji, polegającą na "wprowadzaniu ludzi w role społeczne i zawodowe, które zastali i które są do objęcia" 
oraz wprowadzaniu w istniejący porządek społeczny, który jednocześnie przedstawiany jest jako dobry i/lub konieczny i/lub niezmienialny»" (Kwieciński, 1995, s. 21; Kopińska, 2017b, s. 105). Przykładem takiego wymagania jest: „słucha z uwagą wypowiedzi nauczyciela, innych osób $\mathrm{z}$ otoczenia, w różnych sytuacjach życiowych, wymagających komunikacji i wzajemnego zrozumienia; okazuje szacunek wypowiadającej się osobie".

3. „Wymagania oceniane jako emancypacyjne to takie, których spełnienie wpisuje się $\mathrm{w}$ funkcję emancypacyjną edukacji polegającą na tym, by przygotować ludzi do przekraczania narzuconych ograniczeń, do zmieniania otaczającej rzeczywistości na lepszą" (Kwieciński, 1995, s. 21; Kopińska, 2017b, s. 105). Przykładem wymagania ocenionego jako emancypacyjne jest: „rozpoznaje przyczyny, przejawy i skutki nietolerancji i stygmatyzacji oraz przedstawia możliwe sposoby przeciwstawiania się tym zjawiskom".

Sformułowane wcześniej pytanie badawcze wymaga doprecyzowania w odniesieniu do kryteriów oceny. Porównania kompetencji społecznych i obywatelskich artykułowanych $\mathrm{w}$,starych" podstawach programowych do szkoły podstawowej i gimnazjum oraz „nowej” podstawie programowej do ośmioletniej szkoły podstawowej dokonam w zakresie czterech obszarów:

1. Struktura analizowanych wymagań $\mathbf{Z}$ podstaw programowych uwzględniająca ich podział na obszar wiedzy, umiejętności i postaw, a dokładnie porównanie liczebności wymagań wpisujących się w kompetencje społeczne i obywatelskie z uwzględnieniem obszaru wiedzy, umiejętności i postaw.

2. Ocena analizowanych wymagań $\mathrm{z}$ podstaw programowych $\mathrm{w}$ odniesieniu do funkcji szkoły / edukacji, a dokładnie liczebność wymagań ocenianych jako rekonstrukcyjne, adaptacyjne i emancypacyjne.

3. Kategorie analityczne / efekty uczenia się eksponowane w badanych wymaganiach $\mathbf{z}$ podstaw programowych, czyli takie, których liczebność jest najwyższa.

4. Kategorie analityczne / efekty uczenia się nieobecne lub marginalizowane $w$ badanych wymaganiach $z$ podstaw programowych, czyli takie, które nie zostały zidentyfikowane lub pojawiły się jeden raz.

\section{Wyniki badań}

W nowej podstawie programowej dla szkoły podstawowej zidentyfikowano 897 wymagań wpisujących się swoim zakresem w kompetencje społeczne i obywatelskie. To ogromy wzrost w stosunku do i tak licznych 569 wymagań 
obecnych w dotychczasowych podstawach programowych dla sześcioletniej szkoły podstawowej i gimnazjum łącznie. Oznacza to wzrost o ponad 50\% wymagań mimo krótszego o rok okresu nauki oraz mimo faktu, że w nowej podstawie programowej wymagania są formułowane w zasadzie dwukrotnie (dla klas I-III oraz IV-VIII), a trzeci raz - dla VII-VIII klasy tylko w odniesieniu do przedmiotów: język polski, język obcy nowożytny, historia, matematyka, informatyka, wychowanie fizyczne. Sama jednak liczba wymagań nie jest dostateczną podstawą do wyciągania wniosków na temat struktury owych wymagań. W związku z tym proponuję się im przyjrzeć przy uwzględnieniu podziału na obszar wiedzy, umiejętności i postaw (wykresy 1. i 2.).

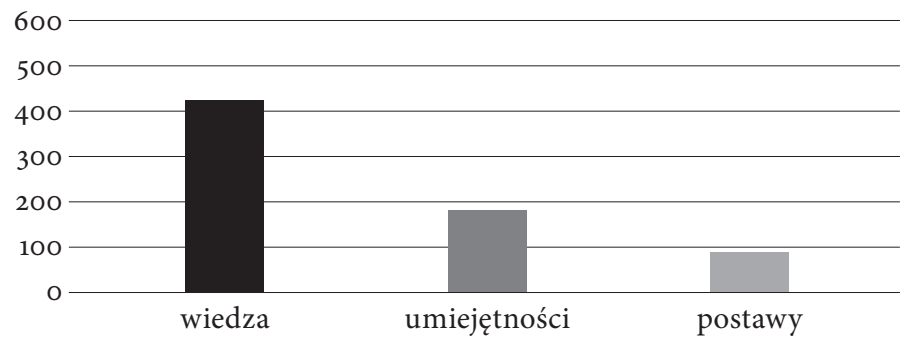

Wykres 1. Liczba wymagań ${ }^{*}$ podstawach programowych kształcenia ogólnego w zakresie kompetencji społecznych i obywatelskich z podziałem na obszar wiedzy, umiejętności i postaw - „stara” podstawa programowa do sześcioletniej szkoły podstawowej i gimnazjum łącznie

* Wymagania szczegółowe w podstawie programowej, które stanowiły jednostki analizy mają niejednokrotnie charakter rozbudowany i składają się z kilku efektów uczenia się należących czasem do różnych obszarów. Dla większej przejrzystości, wykres nie przedstawia wymagań o charakterze „mieszanym”. Wymagania te zostały zakwalifikowane do tych obszarów, do których należą. Jeżeli zatem wymaganie łączy w sobie efekty uczenia się pochodzące np. z obszaru wiedzy i umiejętności, zostało zakwalifikowane zarówno do obszaru wiedzy, jak i do obszaru umiejętności. Dlatego też suma wymagań przedstawionych na wykresie jest większa niż 569. Źródło: badania własne.

Z analizy obu wykresów wynika, że w nowej podstawie programowej wzrost dotyczy wszystkich grup wymagań (w przypadku obszaru wiedzy o 48\%; w przypadku obszaru umiejętności o $82 \%$, a w przypadku postaw o $33 \%$ w stosunku do „starych” podstaw programowych), z czego największy - dotyczy zakładanych umiejętności. Jeżeli jednak przyjrzymy się relacji między poszczególnymi obszarami, to okazuje się, że kształtują się one na podobnym poziomie w obu badanych dokumentach. I tak w nowej podstawie programowej na dwa wymagania zawierające w sobie efekty uczenia się mieszczące się $\mathrm{w}$ kategorii wiedzy przypada jedno z zakresu umiejętności (w starej podstawie programowej relacja ta wynosiła 2,5:1), zaś na 3,5 wymaga- 


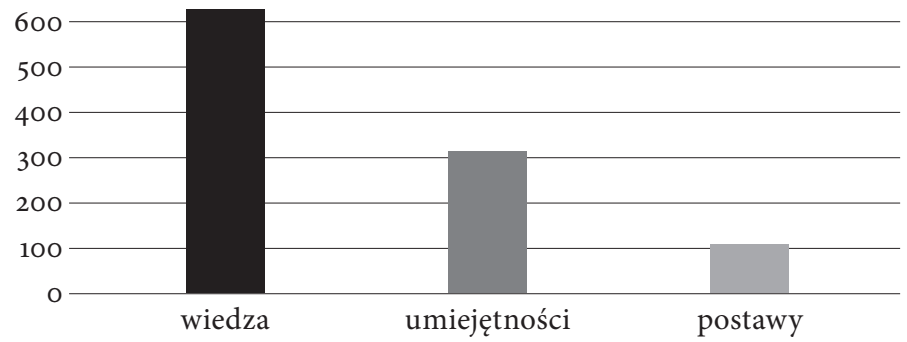

Wykres 2. Liczba wymagań ${ }^{\star}$ podstawach programowych kształcenia ogólnego w zakresie kompetencji społecznych i obywatelskich z podziałem na obszar wiedzy, umiejętności i postaw - „nowa” podstawa programowa do ośmioletniej szkoły podstawowej

* Wymagania szczegółowe w podstawie programowej, które stanowiły jednostki analizy mają niejednokrotnie charakter rozbudowany i składają się z kilku efektów uczenia się należących czasem do różnych obszarów. Dla większej przejrzystości, wykres nie przedstawia wymagań o charakterze „mieszanym”. Wymagania te zostały zakwalifikowane do tych obszarów, do których należą. Jeżeli zatem wymaganie łączy w sobie efekty uczenia się pochodzące np. z obszaru wiedzy i umiejętności, zostało zakwalifikowane zarówno do obszaru wiedzy, jak i do obszaru umiejętności. Dlatego też suma wymagań przedstawionych na wykresie jest większa niż 897. Źródło: badania własne.

nia mieszczące się w obszarze umiejętności przypada jedno z obszaru postaw (w starej podstawie stosunek ten wynosił 2,5:1).

Interesujących danych w tym zakresie dostarczają kolejne wykresy (3. i 4.).

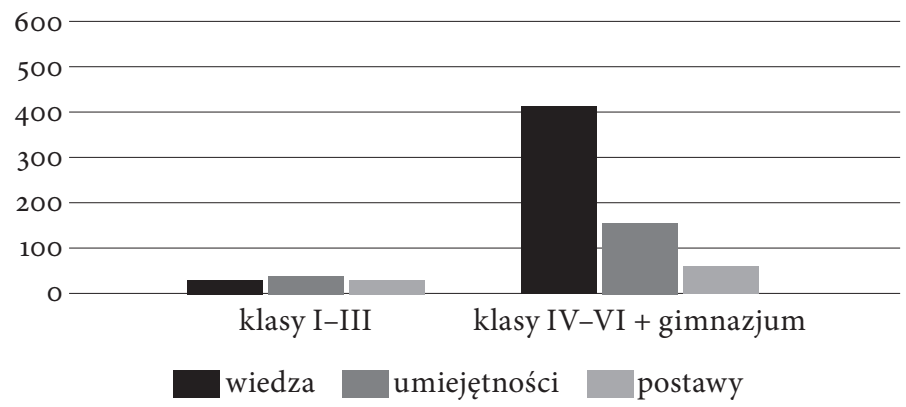

Wykres 3. Liczba wymagań w podstawach programowych kształcenia ogólnego w zakresie kompetencji społecznych i obywatelskich z podziałem na obszar wiedzy, umiejętności i postaw - „stara” podstawa programowa do sześcioletniej szkoły podstawowej i gimnazjum $\mathrm{z}$ wydzielonym pierwszym etapem edukacyjnym (klasy I-III)

Źródło: badania własne. 


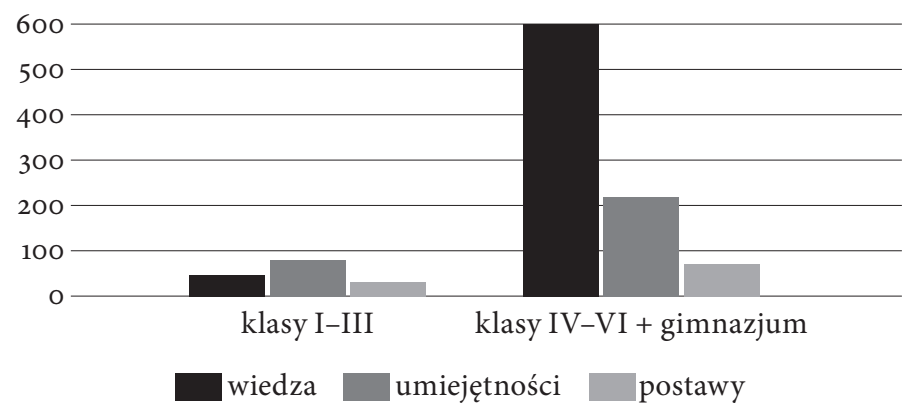

Wykres 4. Liczba wymagań w podstawach programowych kształcenia ogólnego w zakresie kompetencji społecznych i obywatelskich z podziałem na obszar wiedzy, umiejętności i postaw - „nowa” podstawa programowa do ośmioletniej szkoły podstawowej z wydzielonym pierwszym etapem edukacyjnym (kasy I-III)

Źródło: badania własne.

Z wykresów tych wynika, że największy wzrost liczby wymagań zawierających efekty uczenia się odnoszące się do obszaru umiejętności w nowej podstawie programowej dotyczy pierwszego etapu edukacyjnego (klasy I-III). Jednocześnie liczba wymagań na tym etapie edukacyjnym wpisujących się w pozostałe obszary nie ulega, w porównaniu z obszarem umiejętności, tak dużym zmianom (liczba wymagań mieszczących się wobszarze wiedzy w starej podstawie programowej - 25, w nowej - 39; liczba wymagań mieszczących się w obszarze umiejętności w starej podstawie programowej - 33, w nowej - 83; liczba wymagań mieszczących się w obszarze postaw w starej podstawie programowej - 23, w nowej - 24). Warto przy tym zauważyć, że nowa podstawa programowa do pierwszego etapu edukacyjnego zmienia strukturę artykułowanych tam kompetencji społecznych i obywatelskich nie tylko poprzez istotny wzrost liczby wymagań wpisujących się w obszar umiejętności, ale również poprzez zmianę proporcji tych wymagań. Pierwszy etap edukacyjny był w starej podstawie programowej identyfikowany jako jedyny, na którym istniała względna harmonia między wymaganiami zaliczanymi do poszczególnych obszarów: wiedzy, umiejętności i postaw (Symonowicz-Jabłońska i Wieczór, 2017, s. 116-117). Obecna struktura nie daje podstaw, by stwierdzić taką równowagę. Dysproporcje dotyczące liczby wymagań z zakresu kompetencji społecznych i obywatelskich wpisujących się w poszczególne, wskazane wyżej obszary, dotyczą obecnie również pierwszego etapu edukacyjnego, choć tu zdecydowanie dominują umiejętności, a nie - wiedza, jak to ma miejsce w dalszej edukacji. 
Ocena kompetencji społecznych i obywatelskich, artykułowanych zarówno w starych, jak i w nowych podstawach programowych w kontekście funkcji szkoły, upoważnia do wniosku, że tak jak to było w przypadku „starej” podstawy programowej, tak i w "nowej” zdecydowanie dominują wymagania o charakterze rekonstrukcyjnym i adaptacyjnym (wykres 5. i 6.).

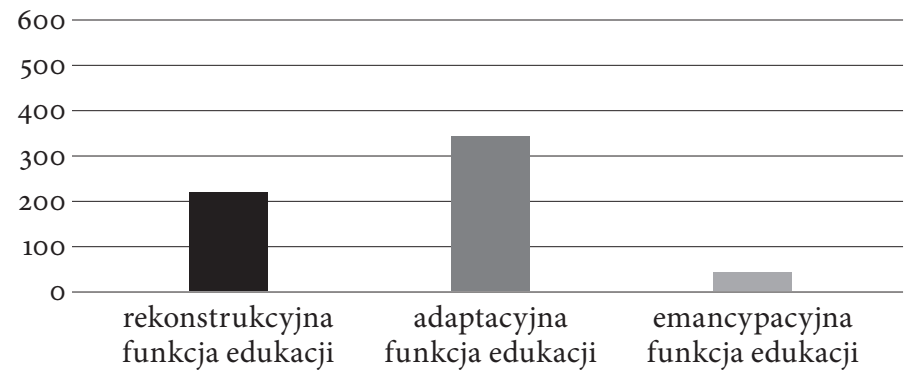

Wykres. 5. Liczba wymagań ${ }^{*} \mathrm{w}$ podstawach programowych kształcenia ogólnego w zakresie kompetencji społecznych i obywatelskich z podziałem na przypisywane im funkcje - „stara” podstawa programowa do sześcioletniej szkoły podstawowej i gimnazjum łącznie

* Wymagania szczegółowe w podstawie programowej, które stanowiły jednostki analizy mają niejednokrotnie charakter rozbudowany i składają się z kilku efektów uczenia. Część z nich została oceniona jako wymagania łączące w sobie różne funkcje. Wymagania ocenione $w$ ten sposób zostały dla większej przejrzystości uwzględnione w każdej z tych kategorii. Dlatego też suma wymagań przedstawionych na wykresie jest większa niż 569. Źródło: badania własne.

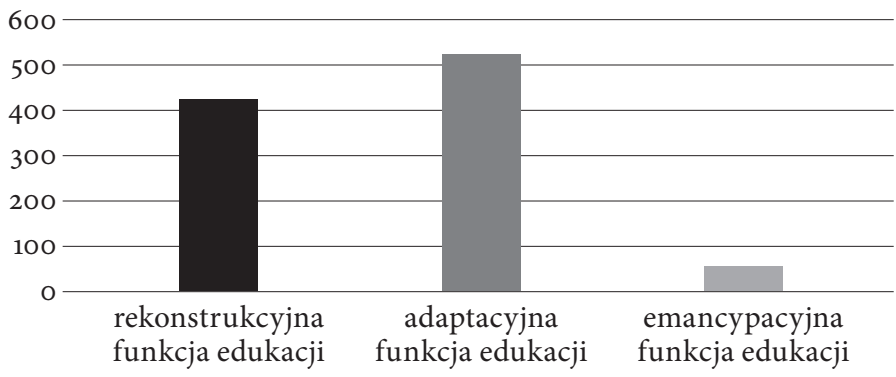

Wykres 6. Liczba wymagań ${ }^{\star}$ wodstawach programowych kształcenia ogólnego w zakresie kompetencji społecznych i obywatelskich z podziałem na przypisywane im funkcje - „nowa” podstawa programowa do ośmioletniej szkoły podstawowej

* Wymagania szczegółowe w podstawie programowej, które stanowiły jednostki analizy mają niejednokrotnie charakter rozbudowany i składają się z kilku efektów uczenia. Część z nich została oceniona jako wymagania łączące w sobie różne funkcje. Wymagania ocenione w ten sposób zostały dla większej przejrzystości uwzględnione w każdej z tych kategorii. Dlatego też suma wymagań przedstawionych na wykresie jest większa niż 897. Źródło: badania własne. 
Szczegółowa analiza wskazuje, że oprócz wzrostu liczby wymagań wpisujących się $w$ każdą z tych grup nie zmienia się zasadniczo ich relacja w stosunku do ogólnej liczby badanych wymagań w zakresie funkcji adaptacyjnej ( $w$ „starej” podstawie programowej wymagania ocenione jako te, które realizują adaptacyjną funkcję szkoły stanowiły 61\% badanych wymagań, w nowej - blisko 60\%) i emancypacyjnej ( $\mathrm{w}$ „starej” podstawie programowej wymagania ocenione jako te, które realizują emancypacyjną funkcję szkoły stanowiły $6,8 \%$ badanych wymagań, w nowej $-6,5 \%$ ). Wzrósł natomiast procent tych wymagań, które zawierały w sobie efekty uczenia się wpisujące się w rekonstrukcyjną funkcję edukacji - w starej podstawie programowej stanowiły one $38 \%$ badanych wymagań, w nowej - $48 \%$.

Istotne w kontekście prowadzonej analizy jest również to, jakie kategorie/ efekty uczenia się w zakresie kompetencji społecznych i obywatelskich dominują w nowych podstawach programowych, a jakie zostały z nich wykluczone lub pozostawione na marginesie. Należy przy tym zwrócić uwagę, że ocena liczby efektów wpisujących się w poszczególne kategorie analityczne, przedstawiona za pomocą wyników tabelarycznych, wymaga wielostronnej analizy. Istotne jest np. usytuowanie tych kategorii na poszczególnych etapach edukacyjnych, w poszczególnych przedmiotach, a i tak nie zawsze jest to łatwe do oceny. Nieco łatwiej jest natomiast ocenić te kategorie, które szczególnie się wyróżniają, czyli uzyskują najwyższe i najniższe liczebności. Pozwala to również na wniosek, na czym tak naprawdę koncentruje się podstawa programowa, a co pomija.

Zestawienie najwyżej notowanych kategorii w obu podstawach programowych przedstawia tabela 1.

W tabeli 1. wyróżniłam po trzy najwyżej „notowane” kategorie w obszarze wiedzy, umiejętności i postaw w porównywanych dokumentach. Analiza tej tabeli wskazuje, że mimo znacznego wzrostu liczby kategorii spowodowanej ogólnym wzrostem liczby wymagań w nowej podstawie programowej, ich struktura w zakresie dominujących efektów uczenia się nie zmienia się mocno. I tak, w obszarze wiedzy wciąż dominuje wiedza na temat historii i dziedzictwa kulturowego kraju oraz znajomość głównych wydarzeń i trendów w europejskiej i światowej historii, wiedza na temat dziedzictwa kulturowego Europy $i$ świata, choć należy zauważyć, że znaczenie tej ostatniej kategorii w relacji do ogólnej liczby badanych wymagań zmniejsza się o połowę. Za to na znaczeniu zyskuje nieco kategoria wiedza na temat sposobów zapewnienia sobie zdrowia fizycznego (wymagania w nikłym stopniu odnoszą się do zdrowia psychicznego), a wymagania, w których odnotowano tę kategorię miesz- 
Tabela 1. Najliczniej reprezentowane kategorie analityczne w zakresie kompetencji społecznych i obywatelskich - porównanie „starej” (sześcioletnia szkoła podstawowa i gimnazjum - łącznie) i „nowej” podstawy programowej (ośmioletnia szkoła podstawowa)

\begin{tabular}{|c|c|c|c|c|}
\hline \multirow[t]{2}{*}{ Kategoria analityczna / efekt uczenia się } & \multicolumn{2}{|c|}{$\begin{array}{l}\text { „Stare" podsta- } \\
\text { wy programo- } \\
\text { we }(\mathrm{N}=569)\end{array}$} & \multicolumn{2}{|c|}{$\begin{array}{l}\text { "Nowe" podsta- } \\
\text { wy programo- } \\
\text { we }(\mathrm{N}=897)\end{array}$} \\
\hline & $\mathrm{n}^{*}$ & $\%^{* *}$ & $\mathrm{n}$ & $\%$ \\
\hline \multicolumn{5}{|l|}{ Obszar wiedzy } \\
\hline $\begin{array}{l}\text { wiedza na temat historii i dziedzictwa kulturowego } \\
\text { kraju }\end{array}$ & 114 & 20,04 & 180 & 20,06 \\
\hline $\begin{array}{l}\text { wiedza na temat sposobów zapewnienia sobie zdrowia } \\
\text { fizycznego (i psychicznego) }\end{array}$ & 40 & 7,03 & 100 & 11,15 \\
\hline $\begin{array}{l}\text { znajomość głównych wydarzeń i trendów w europej- } \\
\text { skiej i światowej historii, wiedza na temat dziedzictwa } \\
\text { kulturowego Europy i świata }\end{array}$ & 114 & 20,04 & 98 & 10,92 \\
\hline znajomość zasad etyki & 2 & 0,35 & 50 & 5,57 \\
\hline $\begin{array}{l}\text { rozumienie zasad postępowania i reguł zachowania } \\
\text { ogólnie przyjętych w różnych społeczeństwach i środo- } \\
\text { wiskach }\end{array}$ & 33 & 5,80 & 32 & 3,57 \\
\hline \multicolumn{5}{|l|}{ Obszar umiejętności } \\
\hline $\begin{array}{l}\text { umiejętność nadawania, odbierania i kontrolowania } \\
\text { komunikatów werbalnych i niewerbalnych }\end{array}$ & 69 & 12,13 & 57 & 6,35 \\
\hline $\begin{array}{l}\text { umiejętność podejmowania działań służących zapew- } \\
\text { nieniu zdrowia fizycznego (i psychicznego) }\end{array}$ & 8 & 1,41 & 44 & 4,91 \\
\hline $\begin{array}{l}\text { umiejętność zachowania się zgodnie z regułami i zasa- } \\
\text { dami panującymi w różnych środowiskach }\end{array}$ & 11 & 1,93 & 41 & 4,57 \\
\hline umiejętność oceny działań innych & 26 & 4,57 & 31 & 3,46 \\
\hline $\begin{array}{l}\text { umiejętność wyrażania własnego zdania, prezentacji } \\
\text { w mowie i/lub na piśmie własnych pomysłów }\end{array}$ & 13 & 2,28 & 10 & 1,11 \\
\hline \multicolumn{5}{|l|}{ Obszar postaw } \\
\hline poszanowanie praw człowieka & 12 & 2,11 & 13 & 1,45 \\
\hline szacunek dla różnic & 1 & 0,18 & 10 & 1,12 \\
\hline $\begin{array}{l}\text { gotowość do przyjmowania odpowiedzialności zwią- } \\
\text { zanej z uczestnictwem w różnych wspólnotach, funk- } \\
\text { cjonowaniem w różnych rolach społecznych }\end{array}$ & 12 & 2,11 & 10 & 1,12 \\
\hline $\begin{array}{l}\text { gotowość przyjmowania odpowiedzialności za skutki } \\
\text { działań własnych }\end{array}$ & 4 & 0,70 & 10 & 1,12 \\
\hline poszanowanie wartości i prywatności innych osób & 3 & 0,53 & 10 & 1,12 \\
\hline $\begin{array}{l}\text { przekonanie o znaczeniu zdrowia psychicznego i fi- } \\
\text { zycznego oraz o konieczności zapewnienia sobie opty- } \\
\text { malnego poziomu zdrowia fizycznego i psychicznego }\end{array}$ & 10 & 1,76 & 6 & 0,67 \\
\hline
\end{tabular}

* liczby w tabeli oznaczają liczbę wymagań szczegółowych z podstaw programowych, w których zidentyfikowano daną kategorię analityczną; ${ }^{* *}$ procenty w tej tabeli obliczane są w stosunku do $\mathrm{N}$ - ogólnej liczby wymagań z podstaw programowych, które zostały zakwalifikowane do analizy jako te, które mieszczą się w zakresie kompetencji społecznych i obywatelskich. Źródło: badania własne. 
czą się zasadniczo w trzech przedmiotach: biologii, wychowaniu fizycznym i przyrodzie.

$\mathrm{Na}$ oddzielny komentarz zasługuje kategoria znajomość zasad etyki. $\mathrm{Na}$ podstawie danych w tabeli można odczytać zarówno wzrost liczby wymagań w nowych podstawach programowych, których efekty uczenia się wpisują się $w$ tę kategorię, ale także wzrost jej znaczenia w relacji do liczby badanych wymagań. Niestety, 45 spośród 50 wymagań, w których stwierdzono obecność tej kategorii pochodzi z etyki, która jest przedmiotem nieobowiązkowym i w dodatku, jak pokazują badania realizowane przez Fundację Wolność od Religii (2017) jej organizacja w szkołach pozostawia niejednokrotnie wiele do życzenia. Liczba wymagań, w których obecna jest ta kategoria w ramach przedmiotów obowiązkowych jest zatem znacznie mniejsza, a jej udział w strukturze badanych wymagań w porównaniu do innych kategorii z obszaru wiedzy - niewielki.

W obszarze umiejętności w nowej podstawie programowej, tak jak w starej, nadal dominuje umiejętność komunikacyjna związana $\mathrm{z}$ nadawaniem i odbieraniem komunikatów werbalnych i niewerbalnych, choć jej znaczenie w relacji do wszystkich badanych wymagań spadło w stosunku do starych podstaw programowych. Kolejne dwie kategorie eksponowane w nowej podstawie programowej do szkoły podstawowej to umiejętność podejmowania działan stużących zapewnieniu zdrowia fizycznego oraz umiejętność zachowania się zgodnie z regułami i zasadami panującymi w różnych środowiskach. I tu również widoczny jest wzrost (w stosunku do „starych” podstaw programowych) udziału tych kategorii w odniesieniu do ogólnej liczby badanych wymagań.

W obszarze postaw nie widać dużych zmian w zakresie najwyżej notowanych kategorii, co, niestety, biorąc pod uwagę ogólny wzrost liczby wymagań wpisujących się zwłaszcza w obszar wiedzy i umiejętności, powoduje, że mamy tu do czynienia z pewnym spadkiem znaczenia tych kategorii w ogólnej strukturze badanych wymagań. Kategoria o najwyższej liczebności poszanowanie praw człowieka jest reprezentowana, podobnie jak w starych podstawach programowych, głównie przez etykę na pierwszym etapie edukacyjnym ( 5 wymagań) i wychowanie do życia w rodzinie (3 wymagania). Pozostałe wymagania mieszczą się na pierwszym etapie edukacyjnym w edukacji społecznej (1) i wychowaniu fizycznym (1), a na drugim etapie edukacyjnym (klasy IV-VIII) na informatyce (1) i wiedzy o społeczeństwie (2).

Jest jednak jedna różnica w porównaniu ze „starymi” podstawami programowymi, na którą warto zwrócić uwagę. Dotyczy ona kategorii szacunek dla różnic, która w pierwotnym swoim brzmieniu została sformułowana jako: 
szacunek dla różnic, w tym różnic płciowych, religijnych i etnicznych. Ponieważ jednak przykładowe uszczegółowienie, które zostało zawarte w tytule tej kategorii sugeruje, że postawa szacunku skupia się głównie na tych aspektach, zdecydowałam się na rezygnację $\mathrm{z}$ tej części nazwy kategorii, tym bardziej, że żadne z wymagań podstawy programowej nie odwołuje się do szacunku wobec różnic płciowych. Wymagania te odwołują się natomiast do różnic kulturowych, religijnych, związanych z kondycją fizyczną ludzi, poglądami i preferencjami muzycznymi. W porównaniu z jednym wymaganiem związanym $\mathrm{z}$ tą kategorią $\mathrm{w}$ „starych” podstawach programowych, to istotny wzrost. Warto jednak nieco bliżej przyjrzeć się usytuowaniu tych wymagań, by ocenić ich potencjalną rolę. Po pierwsze, trzy spośród owych dziesięciu wymagań mieszczących się w tej kategorii pochodzą z przedmiotów nieobowiązkowych: etyki (1) i wychowania do życia w rodzinie (2). Zatem w ramach przedmiotów obowiązkowych odnajdziemy siedem takich wymagań; dwa $\mathrm{z}$ nich na pierwszym etapie edukacyjnym, a cztery pozostałe $\mathrm{w}$ ciągu pięciu lat nauki zakładane są do realizacji na następujących przedmiotach: geografia (2), wiedza o społeczeństwie (1), muzyka (1), wychowanie fizyczne (1). Ich znaczenie jest zatem niewielkie, choć - rzecz jasna - należy docenić tę zmianę.

W badanych podstawach programowych zarówno „starych”, jaki „nowych” brakuje wielu kategorii, które są istotne z punktu widzenia kompetencji obywatelskich. Tabela 2. przedstawia sporą grupę tych kategorii, które albo w ogóle nie występują w nowej podstawie programowej, albo pojawiają się tylko raz w ramach całej ośmioletniej edukacji.

Tabela 2. Nieobecne / najmniej liczne kategorie analityczne w zakresie kompetencji społecznych i obywatelskich - porównanie „starej” (sześcioletnia szkoła podstawowa i gimnazjum - łącznie) i „nowej” podstawy programowej (ośmioletnia szkoła podstawowa)

\begin{tabular}{|l|c|c|}
\hline \multirow{2}{*}{ Kategoria analityczna / efekt uczenia się } & $\begin{array}{c}\text { "Stare" podsta- } \\
\text { wy programo- } \\
\text { we (N=569) }\end{array}$ & $\begin{array}{c}\text { "Nowe" podsta- } \\
\text { wy programo- } \\
\text { we (N=897) }\end{array}$ \\
\cline { 2 - 3 } & $\mathrm{n}$ & $\mathrm{n}$ \\
\hline $\begin{array}{l}\text { wiedza na temat roli i znaczenia konfliktów i kontesta- } \\
\text { cji w państwie }\end{array}$ & 0 & 0 \\
\hline wiedza na temat form sprzeciwu obywateli & 0 & 0 \\
\hline $\begin{array}{l}\text { wiedza na temat (innych niż wybory) sposobów / form } \\
\text { uczestnictwa w procesach podejmowania decyzji na } \\
\text { poziomie krajowym }\end{array}$ & 1 & 0 \\
\hline $\begin{array}{l}\text { wiedza na temat (innych niż wybory) sposobów / form } \\
\text { uczestnictwa w procesach podejmowania decyzji na } \\
\text { poziomie europejskim }\end{array}$ & 1 & 0 \\
\hline
\end{tabular}




\begin{tabular}{|c|c|c|}
\hline \multirow[t]{2}{*}{ Kategoria analityczna / efekt uczenia się } & $\begin{array}{l}\text { "Stare" podsta- } \\
\text { wy programo- } \\
\text { we }(\mathrm{N}=569)\end{array}$ & $\begin{array}{l}\text { "Nowe" podsta- } \\
\text { wy programo- } \\
\text { we }(\mathrm{N}=897)\end{array}$ \\
\hline & $\mathrm{n}$ & $\mathrm{n}$ \\
\hline znajomość i zastosowanie pojęcia praw obywatelskich & 5 & 1 \\
\hline $\begin{array}{l}\text { wiedza na temat sposobów rozwiązywania konflik- } \\
\text { tów }\end{array}$ & 6 & 1 \\
\hline $\begin{array}{l}\text { wiedza na temat zasad prowadzenia negocjacji, strate- } \\
\text { gii technik negocjacyjnych }\end{array}$ & o & o \\
\hline $\begin{array}{l}\text { wiedza na temat asertywności i jej znaczenia w kon- } \\
\text { taktach interpersonalnych }\end{array}$ & 7 & 1 \\
\hline $\begin{array}{l}\text { wiedza na temat empatii i jej znaczenia w kontaktach } \\
\text { interpersonalnych }\end{array}$ & 5 & 1 \\
\hline $\begin{array}{l}\text { wiedza na temat tego, czym jest stres i frustracja, wie- } \\
\text { dza na temat relacji między zjawiskiem stresu i fru- } \\
\text { stracji }\end{array}$ & 1 & 1 \\
\hline umiejętność rozumienia różnych punktów widzenia & $\mathrm{O}$ & o \\
\hline $\begin{array}{l}\text { umiejętność obrony własnych poglądów wyrażanych } \\
\text { publicznie }\end{array}$ & o & 1 \\
\hline $\begin{array}{l}\text { umiejętność uczestnictwa w demokratycznych pro- } \\
\text { cesach podejmowania decyzji na poziomie lokalnym, } \\
\text { krajowym, europejskim }\end{array}$ & o & o \\
\hline $\begin{array}{l}\text { umiejętność nazywania własnych problemów i roz- } \\
\text { mawiania o nich }\end{array}$ & 2 & 1 \\
\hline $\begin{array}{l}\text { umiejętność konstruktywnego porozumiewania się } \\
\text { w różnych środowiskach }\end{array}$ & o & 1 \\
\hline umiejętność tworzenia klimatu zaufania & 1 & o \\
\hline $\begin{array}{l}\text { umiejętność radzenia sobie ze stresem i frustracją } \\
\text { i wyrażania ich w konstruktywny sposób }\end{array}$ & o & 1 \\
\hline $\begin{array}{l}\text { gotowość do oceniania działań osób, którymi się kie- } \\
\text { ruje }\end{array}$ & o & 1 \\
\hline $\begin{array}{l}\text { gotowość do uczestnictwa w demokratycznych pro- } \\
\text { cesach podejmowania decyzji na poziomie lokalnym, } \\
\text { krajowym, europejskim }\end{array}$ & 1 & 1 \\
\hline wspieranie różnorodności i spójności społecznej & o & 1 \\
\hline $\begin{array}{l}\text { negatywna ocena uprzedzeń, rasizmu i dyskryminacji } \\
\text { oraz gotowość do pokonywania uprzedzeń }\end{array}$ & 2 & 1 \\
\hline $\begin{array}{l}\text { gotowość zmiany własnej opinii i osiągania kompro- } \\
\text { misu }\end{array}$ & o & 1 \\
\hline $\begin{array}{l}\text { zaufanie i lojalność wobec demokratycznych instytu- } \\
\text { cji }\end{array}$ & o & o \\
\hline zainteresowanie komunikacją międzykulturo & $\mathrm{o}$ & 1 \\
\hline
\end{tabular}

Źródło: badania własne.

$\mathrm{Z}$ tabeli 2. wynika, że w całym ośmioletnim cyklu nauczania, podobnie zresztą jak w przypadku „starych” podstaw programowych, nie założono nawet, by wiedza, umiejętności i postawy związane z uczestnictwem w demo- 
kratycznych procesach podejmowania decyzji, poza wyborami, były czymś istotnym. Nie ma też mowy o kontestacji i sprzeciwie obywateli poza tym, który mieści się w procedurach odwoławczych. W dobie zalewu informacjami, nowa podstawa programowa do ośmioletniej szkoły podstawowej nie eksponuje umiejętności krytycznej oceny ( $w$ starych podstawach programowych - 6, w nowych - 15), a w żadnym razie nie wiąże tego z krytyczną oceną poszczególnych rozwiązań lub praktyk związanych z polityką i/lub prawem.

Wspominane wcześniej dziesięć wymagań związanych z kategorią szacunku dla różnic nie znajduje wzmocnienia w takich kategoriach, jak wsparcie dla różnorodności, umiejętność rozumienia różnych punktów widzenia, czy wreszcie postawa jednoznacznej negatywnej oceny wszelkich uprzedzeń, dyskryminacji.

Nadal podstawy programowe nie zwracają uwagi na konieczność systematycznego rozwijania umiejętności obrony własnych poglądów wyrażanych publicznie, konstruktywnego porozumiewania się czy gotowości do osiągania kompromisu.

Podsumowując, porównanie nowych podstaw programowych do ośmioletniej szkoły podstawowej ze starymi jej odpowiednikami w zakresie zakładanych tam kompetencji społecznych i obywatelskich pozwala stwierdzić, że:

1. W nowej podstawie programowej istotnie wzrosła (o ponad 50\%) i tak już ogromna liczba wymagań szczegółowych. Wzrost ten spowodował istotną zmianę struktury wymagań zaliczanych do obszaru wiedzy, umiejętności i postaw tylko na pierwszym etapie edukacyjnym. Struktura wymagań w dalszej części edukacji pozostawiła tę samą hierarchię, która obowiązywała $\mathrm{w}$ „starych” podstawach programowych; zdecydowanie dominuje wiedza, w drugiej kolejności liczą się umiejętności (choć tych jest o połowę mniej niż wymagań związanych z wiedzą), natomiast postawy zajmują tu pozycję raczej marginalną.

2. Zmiana podstawy programowej nie zmienia także struktury wymagań w zakresie przypisywanych im funkcji edukacji. Tak jak w „starych” podstawach, tak i tu dominują wymagania oceniane jako adaptacyjne, na drugim miejscu pod względem liczebności znajdują się wymagania rekonstrukcyjne. Niewielki zaś odsetek stanowią te, które zostały ocenione jako emancypacyjne. W nowych podstawach programowych umacnia się jednak (w relacji to pozostałych obszarów) rola wymagań ocenionych jako te, które wpisują się w rekonstrukcyjną funkcję edukacji.

3. W zakresie kompetencji społecznych i obywatelskich, artykułowanych w nowej podstawie programowej eksponowana jest przede wszystkim, 
tak jak w „starych” podstawach programowych, rekonstrukcja wiedzy historycznej. Istotne są również wiedza i umiejętności związane $z$ zapewnieniem sobie zdrowia fizycznego. Kategorie te zyskują na znaczeniu w porównaniu ze "starymi” podstawami programowymi. Wzrasta również znaczenie adaptacyjnej umiejętności zachowania się zgodnie $z$ regułami i zasadami panujacymi w różnych środowiskach. Umiejętność najbardziej eksponowana w nowej podstawie programowej również pozostaje niezmieniona. Jest to umiejętność komunikacyjna, ale rozumiana w kategoriach nadawania, odbierania i kontrolowania komunikatów werbalnych i niewerbalnych. Nie chodzi tu zatem o rozwiązywanie problemów, konstruktywne porozumiewanie się, tworzenie klimatu zaufania czy też umiejętne konstruowanie argumentów i odwagę obrony własnego stanowiska w sytuacjach publicznych.

Tak jak „stare”, tak i nowa podstawa programowa pomija zarówno wiedzę, umiejętności, jak i postawy związane z uczestnictwem w demokratycznych procesach podejmowania decyzji, a zwracanie uwagi na istotne w warunkach demokratycznych wartości pozostaje wciąż na marginesie i /lub w granicach przedmiotów nieobowiązkowych: etyki - traktowanej jako „konkurencja” dla dominującej w szkołach religii oraz wychowania do życia w rodzinie - przedmiotu będącego płaszczyzną sporów ideologicznych ${ }^{13}$.

\section{Konkluzja i dyskusja}

„Nowa” podstawa programowa wprowadza niewielkie zmiany w zakresie ogólnej oceny kompetencji społecznych i obywatelskich tam artykułowanych. Oparta jest na tej samej, co „stara”, techniczno-scjentystycznej orientacji. Utrwala tradycyjny - transmisyjny model edukacji i obywatelstwo adaptacyjne (Biesta, 2009a, 2009b), oparte na metastrategii utrwalającej (de Cillia, Reisigl i Wodak, 1999, s. 160-161; Krzyżanowski, 2008, s. 282-283). Wniosek ten wynika zarówno z ogólnej analizy struktury zapisanych tam wymagań, jak i analiz szczegółowych, odnoszących się zarówno do eksponowanych, jak i marginalizowanych kategorii analitycznych.

Warto przy tym podkreślić jeszcze jedno: wyniki analiz dotyczących wymagań szczegółowych podstawy programowej w zakresie kompetencji społecznych i obywatelskich, w zestawieniu z celami kształcenia ogólnego w szkole podstawowej wskazanymi na wstępie dokumentu, obnażają deklaratywność tych ostatnich (podobne wnioski skonstruowano na podstawie

13 Dla oceny stanu rzeczy - warto przeczytać „nową” podstawę programową do przedmiotu wychowanie do życia w rodzinie. 
analizy „starych” podstaw programowych (Solarczyk-Szwec, 2017, s. 193-194)). Analiza wymagań szczegółowych nie potwierdza tego, jakoby podstawa programowa zakładała realizowanie takich celów jak zwłaszcza: ukierunkowanie ucznia ku wartościom (niezależnie od sposobu rozumienia tego sformułowania), rozwijanie u uczniów umiejętności krytycznego myślenia czy kształtowanie postawy otwartej wobec świata i innych ludzi, czy aktywności w życiu społecznym. Z pewnością natomiast sprzyja wzmacnianiu tożsamości narodowej, przywiązaniu do historii i tradycji narodowych. Wskazuje to jednocześnie na niespójność tego dokumentu. Każda odpowiedź na pytanie: czy owa niespójność ma charakter zamierzony, czy nie, jest niepokojąca. Odpowiedź przecząca odsłania niekompetencję i brak poczucia odpowiedzialności za ustalenie dokumentu w takim kształcie. Odpowiedź twierdząca obnaża ukryte założenia dotyczące edukacji społecznej i obywatelskiej, które mogą być usprawiedliwiane właśnie za pomocą przytaczanych wyżej, ogólnych celów kształcenia.

Metodologia, a co za tym idzie, zaprezentowane tu wyniki analiz mogą być krytykowane. Dyskusyjne może być ujęcie danych o charakterze jakościowym w sposób liczbowy. Można argumentować, że nie ilość, lecz jakość realizacji poszczególnych wymagań wpływa na ostateczny kształt edukacji, a sformułowanie celów kształcenia na poziomie ogólnym podnosi ich rangę i wystarczy do tego, by działania $\mathrm{z}$ tym związane pojawiły się $\mathrm{w}$ toku edukacji. Zgadzam się z taką argumentacją. Niemniej warto podkreślić, że zaprezentowane wyniki analiz nie stanowią diagnozy praktyki edukacyjnej, tylko odnoszą się do zakładanego przez państwo kształtu tej edukacji. Po drugie, wykorzystanie danych liczbowych do analizy podstawy programowej ma na celu ułatwienie oceny tego rozbudowanego dokumentu. Po trzecie, o ile można mieć wątpliwości co do oceny określonych liczebności poszczególnych kategorii analitycznych, to zdecydowanie nie budzi wątpliwości ocena kategorii uzyskujących największe i najmniejsze liczebności. Po czwarte, jeżeli założymy, że cele kształcenia przypisane ogólnie szkole podstawowej są istotniejsze o tego, co jest artykułowane w ramach wymagań szczegółowych, to dlaczego w przypadku jednych celów kształcenia znajdujemy bardzo liczne, wpisujące się w nie wymagania szczegółowe, a w przypadku innych już tak nie jest? Po piąte, w polskich podstawach programowych dominuje sfera "co" (Bernstein, 1990, 182-183; Kopińska, 2017, s. 417-419). Świadczy o tym nie tylko ilość (rosnąca!) wymagań szczegółowych w ogóle, a co za tym idzie, ich objętość w podstawach programowych w stosunku do celów ogólnych i warunków realizacji podstaw programowych, ale również jakość tych ostatnich (Kopińska, 2017c, s. 218-223). Poza tym, o sile sfery „co” przesądza nie tylko 
kształt samych podstaw programowych, ale również kształt innych regulacji prawnych, które podnoszą rangę tego dokumentu, o czym pisałam na wstępie artykułu. Słabość sfery „jak”, czyli pedagogicznego pola rekontekstualizacyjnego (Bernstein, 1990, s. 182-183) skutkuje nie tylko niedostateczną spójnością dokumentu, ale ogromnym de facto znaczeniem wymagań szczegółowych, co dodatkowo wzmacniane jest przez centralistycznie programowaną edukację nie tylko w zakresie treści, ale i organizacji (podział na przedmioty, liczba godzin przypisywanych poszczególnym przedmiotom na poszczególnych etapach, brak faktycznych rozwiązań organizacyjnych umożliwiających różnicowanie tempa kształcenia itp.).

Trudno wyobrazić sobie idealną podstawę programową, niemniej jednak zmiana podstaw programowych, pociągająca za sobą również ogromne koszty, powinna przede wszystkim zmierzać do poprawy tej już istniejącej. Tymczasem stwierdzam, że w zakresie kompetencji społecznych i obywatelskich obecna podstawa nie wprowadza zmian istotnie zmieniających strukturę tych kompetencji, a nadto powiela błędy poprzedniej podstawy programowej, co pozwala przypuszczać, iż ten kosztowny dla państwa zabieg miał charakter polityczny i nie ma nic wspólnego z rzeczywistym reformowaniem edukacji.

\section{BIBLIOGRAFIA}

Bernstein, B. (1990). Odtwarzanie kultury. Przeł. Z. Bokszański, A. Piotrowski, Warszawa: Państwowy Instytut Wydawniczy.

Biesta, G.J.J. (2009a). Good Education in an Age of Measurement: On the Need to Reconnect with the Question of Purpose in Education. Educational Assessment, Evaluation and Accountability, t. 21, 1, 33-46, http://dx.doi.org/10.1007/s11092-008-9064-9.

Biesta, G.J.J. (2009b). What Kind of Citizenship for European Higher Education? Beyond the Competent Active Citizen. European Educational Research Journal, t. 8, 2, 146-158, http:// dx.doi.org/10.2304/eerj.2009.8.2.146.

Cillia, de R., Reisigl, M., Wodak, R. (1999). The Discursive Construction of National Identities. Discourse \& Society, t. 10, 2, 149-173, https://doi.org/10.1177/0957926599010002002.

Fundacja Wolność od Religii (2017). Raport $z$ drugiego badania ankietowego realizowanego w ramach projektu - Dyskryminacja dzieci niewierzacych i nieuczestniczących w lekcjach religii w szkole - realizowanego przez Fundacje Wolność od Religii. Pozyskano z https:// cownoscwszkole.pl/files/17/do-pobrania---content/37/Raport-badania-ankietowe-2017. pdf, (dostęp: 31.07.2018).

Góralska, R., Solarczyk-Szwec, H. (2012). O kompetencjach w kontekście Polskiej Ramy Kwalifikacji dla uczenia się przez całe życie. Edukacja Dorosłych, 2.

Jankowski T. (brw). Taksonomia Blooma, Krathwohla i Simpsona. Pozyskano z http://www.jankowskit.pl/metodyka-nauczania-i-dydaktyka/taksonomia-blooma.html (dostęp: 04.01.2015).

Kopińska, V. (2017a). Edukacja obywatelska w szkole. Krytyczna analiza dyskursu podręczników szkolnych. Toruń: Wydawnictwo Naukowe Uniwersytetu Mikołaja Kopernika.

Kopińska, V. (2017b). Metodologia badań. W: V. Kopińska, H. Solarczyk-Szwec (red.), Kompetencje społeczne i obywatelskie w podstawach programowych kształcenia ogólnego. Analiza krytyczna (s. 91-114). Toruń: Wydawnictwo Naukowe Uniwersytetu Mikołaja Kopernika. 
Kopińska, V. (2017c). Zmiana czy status quo? Krytyczna analiza nowych podstaw programowych do iedzy o społeczeństwie. Przegląd Badań Edukacyjnych, 25 (2), 201-228, http:// dx.doi.org/10.12775/PBE.2017.027.

Kopińska, V., Solarczyk-Szwec, H. (red.) (2017a), Kompetencje społeczne i obywatelskie w podstawach programowych kształcenia ogólnego. Analiza krytyczna. Toruń: Wydawnictwo Naukowe Uniwersytetu Mikołaja Kopernika.

Kopińska, V., Solarczyk-Szwec, H. (2017b). Dokumenty polityczno-oświatowe jako źródło społecznie konstruowanej wiedzy o kompetencjach społecznych i obywatelskich w edukacji szkolnej. W: V. Kopińska, H. Solarczyk-Szwec (red.), Kompetencje społeczne i obywatelskie w podstawach programowych kształcenia ogólnego. Analiza krytyczna (s. 65-83). Toruń: Wydawnictwo Naukowe Uniwersytetu Mikołaja Kopernika.

Krzyżanowski, M. (2008). Konstrukcja tożsamości narodowych i europejskich w polskim dyskursie politycznym po roku 1989; analiza dyskursywno-polityczna. W: A. Duszak, N. Fairclough (red.), Krytyczna Analiza Dyskursu. Interdyscyplinarne podejście do komunikacji społecznej (s. 267-303). Kraków: Towarzystwo Autorów i Wydawców Prac Naukowych UNIVERSITAS;

Kwieciński, Z. (1995). Socjopatologia edukacji. Olecko: Mazurska Wszechnica Nauczycielska.

Rubacha, K. (2008). Metodologia badań nad edukacją. Warszawa: Wydawnictwa Akademickie i Profesjonalne.

Solarczyk-Szwec, H. (2017). Standardy rozwoju społecznego a kompetencje społeczne w podstawach programowych kształcenia ogólnego. W: V. Kopińska, H. Solarczyk-Szwec (red.), Kompetencje społeczne i obywatelskie w podstawach programowych kształcenia ogólnego. Analiza krytyczna (s. 179-197). Toruń: Wydawnictwo Naukowe Uniwersytetu Mikołaja Kopernika.

Solarczyk-Szwec, H., Kopińska, V. (2017). Analiza porównawcza i wnioski końcowe. W: V. Kopińska, H. Solarczyk-Szwec (red.), Kompetencje społeczne i obywatelskie w podstawach programowych kształcenia ogólnego. Analiza krytyczna (s. 215-230). Toruń: Wydawnictwo Naukowe Uniwersytetu Mikołaja Kopernika.

Symonowicz-Jabłońska, I., Wieczór, I. (2017). Kompetencje społeczne i obywatelskie w podstawach programowych I etapu edukacyjnego. W: V. Kopińska, H. Solarczyk-Szwec (red.), Kompetencje społeczne i obywatelskie w podstawach programowych kształcenia ogólnego. Analiza krytyczna (s. 115-131). Toruń: Wydawnictwo Naukowe Uniwersytetu Mikołaja Kopernika.

Lista dokumentów wykorzystanych do stworzenia katalogu kategorii analitycznych:

Polska Rama Kwalifikacji - Raport Referencyjny. Odniesienie Polskiej Ramy Kwalifikacji na rzecz uczenia się przez całe życie do Europejskiej Ramy Kwalifikacji, 2013.

Strategia Rozwoju Kapitału Społecznego 2020. Załącznik do Uchwały nr 61 Rady Ministrów z dnia 26 marca 2013 r. w sprawie przyjęcia „Strategii Rozwoju Kapitału Społecznego 2020 ", M.P. z 2013 r., poz. 378.

Załącznik do Zalecenia Parlamentu Europejskiego i Rady z dnia 18 grudnia 2006 r. w sprawie kompetencji kluczowych w procesie uczenia się przez całe życie - Kompetencje kluczowe w uczeniu się przez całe życie - Europejskie Ramy Odniesienia (L/394).

Lista publikacji wykorzystanych do stworzenia katalogu kategorii analitycznych:

Argyle, M. (2002). Umiejętności społeczne. W: N.J. Mackintosh, A.M. Colman (red.), Zdolności a procesy uczenia się. Poznań: Zysk i S-ka.

Biesta, G.J.J. (2009). What Kind of Citizenship for European Higher Education? Beyond the Competent Active Citizen. European Educational Research Journal, t. 8, 2, 146-158, http:// dx.doi.org/10.2304/eerj.2009.8.2.146

Biesta G.J.J.(2011). Learning Democracy in School and Society. Education, Lifelong Learning and the Politics of Citizenship. Rotterdam: Sense Publishers. 
Hoskins, B., Villalba, E., Van Niljen, D., Barber, C. (2008). Measuring Civic Competence in Europe. Luxembourg: Office for Official Publications of the European Communities.

Martowska, K. (2012). Psychologiczne uwarunkowania kompetencji społecznych. Warszawa: Wydawnictwo Liberi Libri.

Martowska, K., Matczak, A. (2013). Pomiar kompetencji społecznych - prezentacja nowego narzędzia diagnostycznego. W: K. Martowska, A. Matczak, Psychologia Jakości Życia, t. 12, $1,43-56$.

Matczak, A. (2007). Kwestionariusz kompetencji społecznych. Warszawa: Pracownia Testów Psychologicznych Polskiego Towarzystwa Psychologicznego.

Riggio, R.E. (1986). Assessment of basic social skills. Journal of Personality and Social Psycho$\log y, 51,649-660$.

\section{SUMMARY}

\section{The Change of Polish School Core Curriculum} in the Field of Social and Civic Competences. Critical Analysis

A new core curriculum for primary schools became applicable in Poland in the school year 2017/2018. Earlier announcements regarding educational reform emphasized the importance of upbringing in school, highlighting social development of school students and civic education. Therefore, the aim of the research which results are presented in this paper was to determine the scope of changes in the new core curriculum in relation to the social and civic competences articulated there. The method of data collection used in the research was finding secondary sources, and the method of analysing data - content analysis. The results indicate that the "new" core curriculum, like the "old" one, consolidates traditional - transmission model of education and socialization citizenship. This conclusion results both from the general analysis of the structure of the learning outcomes written in the core curriculum as well as detailed analyzes referring to both exposed and marginalized analytical categories. This allows us to believe that the decision to change the core curriculum had nothing to do with the actual reform of education.

KEY WORDS: core curriculum, school, social competences, civic competences 